\title{
Ventral exoskeletal morphology of the trilobite Neodrepanura premesnili from the Cambrian Kushan Formation, Shandong, China
}

\author{
QING LIU, QIANPING LEI \& QIANG OU
}

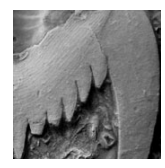

\begin{abstract}
The polymerid trilobite Neodrepanura (family Damesellidae) is one of the most famous and abundant fossils from the Kushan Formation (Cambrian) of the North China Platform. Recent discovery of the first known complete exoskeleton of Neodrepanura premesnili, together with additional material, allows further description of the butterfly-shaped hypostome and wide doublure in this species. These new materials suggest that $N$. premesnili had a carnivorous feeding habit. $•$ Key words: Trilobita, Neodrepanura, Drepanura, hypostome, doublure, Cambrian, China.
\end{abstract}

LIU, Q., LEI, Q. \& OU, Q. 2011. Ventral exoskeletal morphology of the trilobite Neodrepanura premesnili from the Cambrian Kushan Formation, Shandong, China. Bulletin of Geosciences 86(3), 659-664 (3 figures). Czech Geological Survey, Prague. ISSN 1214-1119. Manuscript received March 4, 2011; accepted in revised form July 11, 2011; published online July 27, 2011; issued September 30, 2011.

Qing Liu, State Key Laboratory of Palaeobiology and Stratigraphy, Nanjing Institute of Geology and Palaeontology, Chinese Academy of Sciences, China 210008; Room 404, West Unit, No. 10 Zhongshanqiao Road, Pingjiang District, Suzhou City, Jiangsu Province, China 215005; gaius_julius_caesar@yahoo.cn•Qianping Lei, State Key Laboratory of Palaeobiology and Stratigraphy, Nanjing Institute of Geology and Palaeontology, Chinese Academy of Sciences, China 210008; cicelyapple@126.com・Qiang Ou, Early Life Evolution Laboratory, School of Earth Sciences and Resources, China University of Geosciences, China 100083; ouqiang@126.com

Neodrepanura, which is one of the most famous polymerid trilobites from China, is locally abundant in the Kushan Formation (Cambrian) of the North China Platform (e.g., Zhang 2003, Peng 2007). Known as the "bat-stones", the Neodrepanura-bearing rocks had been first mentioned in a Chinese ancient dictionary (Guo 300 A.D.) dated back to the 4th century, and this comment also represents the oldest written reference to trilobites (Chang 1927, Needham 1959, St. John 2007). The first scientific study of "Neodrepanura" was by the French palaeontologist Bergeron in 1899 , who initially proposed the name Drepanura for this genus. As the name was preoccupied by an insect genus of Family Entomobryidae (Schoett 1891), Özdikmen (2006) replaced the junior homonym with Neodrepanura.

The first known complete exoskeleton of Neodrepanura premesnili (Bergeron 1899), the type species of the genus, was recently reported and described by Liu \& Lei (2010). The new description, highlighting the features of dorsal morphology, helps to correct previous misconceptions of N. premesnili introduced by Kobayashi (1942), based on incomplete material, and widely cited for more than half a century.

Since the publication of our article on the exoskeletal morphology of $N$. premesnili, additional material, including some hypostomes and specimens exhibiting the doublure, has been collected. The additional specimens permit us to describe and interpret the ventral exoskeletal morphology of this species.

\section{Systematic palaeontology}

Repository. - Type and figured materials described in this paper are housed in the Early Life Evolution Laboratory of China University of Geosciences, Beijing (prefix ELEL).

Order Lichida Moore, 1959

Superfamily Dameselloidea Kobayashi, 1935

Family Damesellidae Kobayashi, 1935

Subfamily Drepanurinae Hupé, 1953

\section{Genus Neodrepanura Özdikmen, 2006}

Neodrepanura premesnili (Bergeron, 1899)

Figures 1-3

1899 Drepanura premesnili Bergeron, p. 509, pl. 13, fig. 8.

1902 Drepanura premesnili Bergeron. - Airaghi, p. 10, pl. 1, figs 31,32 . 
1992 Drepanura premesnili Bergeron. - Zhu, p. 355, pl. 119, figs 1,4 .

1996 Drepanura premesnili Bergeron. - Guo et al., p. 129, pl. 10, fig. 12.

2004 Drepanura premesnili Bergeron. - Peng et al., p. 129, pl. 45 , fig. 1.

2010 Neodrepanura premesnili (Bergeron). - Liu \& Lei (see this reference for a detailed synonymy).

Lectotype. - A pygidium on the upper left of the Bergeron's rock slab (E.N.S.M. 9000), figured as pl. 13, fig. 8 by Bergeron (1899); selected by Peng et al. (2004, p. 129).

Material. - Figured specimens include two incomplete exoskeletons (ELEL-LW100020, ELEL-LW100025), four hypostomes (ELEL-LW100014, ELEL-LW100015, ELEL-LW100017, ELEL-LW100018), three librigenae (ELEL-LW100013, ELEL-LW100023, ELEL-LW100024), three cranidia (ELEL-LW100016, ELEL-LW100021, ELEL-LW100026), a thoracic segment (ELEL-LW100019) and a pygidium (ELEL-LW100022). The complete exoskeleton (ELEL-LW100010) is refigured to show anterior morphology of cephalon.

Additional diagnosis. - To the diagnosis of dorsal morphology (see Liu \& Lei 2010), the following characters of ventral morphology are added: Librigenal doublure wide and flat in the genal region, but narrowing and increasingly incurved anteriorly, pleural doublure wide (transverse) and extends under entire pleural spines, pygidial doublure particularly wide. Hypostome butterfly-shaped, shoulders widely spread laterally with sharp ends, posterior border with a pair of deep depressions and a pair of broad marginal spines.

Description. - To the description of dorsal morphology (see Liu \& Lei 2010), the additional description of ventral morphology is given as follows:

Hypostome butterfly-shaped (Figs 1C, D, 2A-D), smooth, noticeably wider (transverse) than long (sagittal). Anterior margin slightly convex medially, but straight abaxially, anterior wings subtriangular. Anterior lobe of middle body sub-ovate and strongly inflated, posterior lobe of middle body crescent and gently convex, short (sagittal \& exsagittal), and slightly wider (transverse) than anterior lobe; middle furrow shallow medially and deepening abaxially. Shoulders large and widely spread laterally as subtriangular extensions with sharp ends. Posterior border inconspicuous medially, widening (exsagittal) abaxially, where it bears a pair of deep depressions and a pair of broad marginal spines projecting strongly rearward, posterior margin gently arched (Figs 2A, B, 3B). Hypostomal doublure smooth, covering most of the shoulders and the posterior border with flexuous inner margin (Figs 2C, D, 3C).

Cephalic doublure consisting of two parts: 1) librigenal doublure, wide (transverse) and flat in the genal region, increasingly incurved and narrow anteriorly (Figs 2E, F, H, 3A), with weak terrace ridges (Fig. 2G, I); 2) occipital doublure, broad medially and narrow abaxially, maximum width (sagittal) occupying about 0.6 width of occipital ring (Fig. 2J). Cranidium without anterior border, without preglabellar field (Fig. 2K-M), rostral plate absent (Fig. 1A, B).

Thoracic doublure consisting of two parts: 1) pleural doublure, wide and smooth, extending under entire pleural spines, ending adaxially into a bar-like structure under fulcrum (Figs 1E, 3A), which comprises a fulcral process anteriorly and a fulcral socket posteriorly (Figs 1F, G, 2O); 2) axial doublure, wide medially and narrowing abaxially, maximum width (sagittal) occupying about 0.5 width of axial ring (Fig. 2N).

Pygidial doublure very wide, extending under pygidial spines, most of the pleural field, and the entire post-axial field as well as a small part of terminal piece, where it forms a depressed area (Figs 2P, Q, 3A). Thin and densely-packed terrace ridges run subparallel to the margin (Fig. 2Q).

Occurrence. - From limestone in the upper part of the Kushan Formation, Neodrepanura Zone, uppermost Guzhangian Stage (Cambrian), Laiwu, Shandong, China.

Discussion. - Several hypostomes were assigned by Monke (1903, pl. 8, figs 7-9) to Neodrepanura premesnili shortly after its establishment. However, the hypostomes described by Monke were erroneously assigned to this species. Walcott (1913, pl. 10, fig. 2e) and Zhang \& Jell (1987, pl. 106, fig. 6) described the correct hypostome of N. premesnili, but it was an incomplete specimen in which the anterior wings were broken off. Kobayashi (1942, pl. 2) published a reconstruction of $N$. premesnili that included not only the dorsal exoskeleton, but also the hypostome, and this reconstruction has been widely cited for more than half a century (e.g., Moore 1959, p. 318, fig. 235). Kobayashi's reconstruction of the hypostome was based on the specimens assigned by Monke (1903, pl. 8, figs 10, 11) to Stephanocare richthofeni. Although these specimens might

Figure 1. Neodrepanura premesnili (Bergeron, 1899), from the Kushan Formation in Laiwu, Shandong, China. • A, B - ELEL-LW100010, complete exoskeleton in obliquely anterior view and close-up of partial cephalon. $\bullet$ C, D - ELEL-LW100020, incomplete exoskeleton in dorsal view and close-up of anterior portion of exoskeleton. $\bullet$ E-G-ELEL-LW100025, incomplete exoskeleton in ventral view, close-up of left part of pleural portion and close-up of right part of pleural portion; scale bars $8 \mathrm{~mm}$ in $\mathrm{A}, \mathrm{C}, \mathrm{E}$ and $3 \mathrm{~mm}$ in $\mathrm{B}, \mathrm{D}, \mathrm{F}, \mathrm{G}$. 


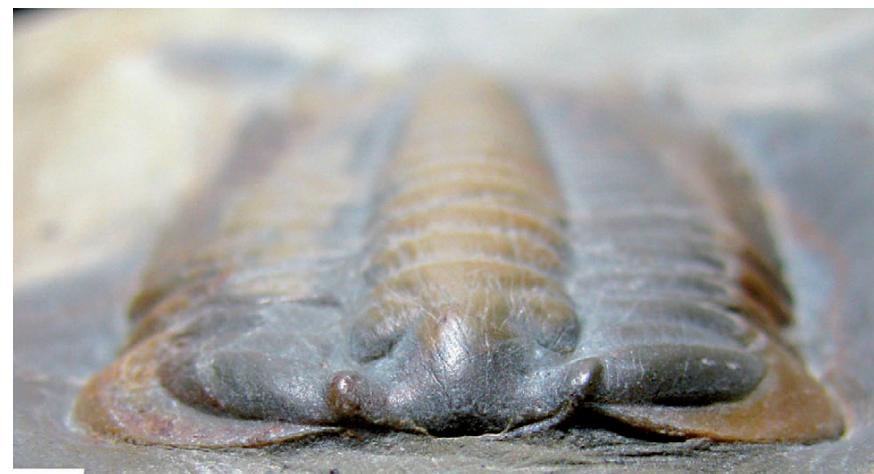

A
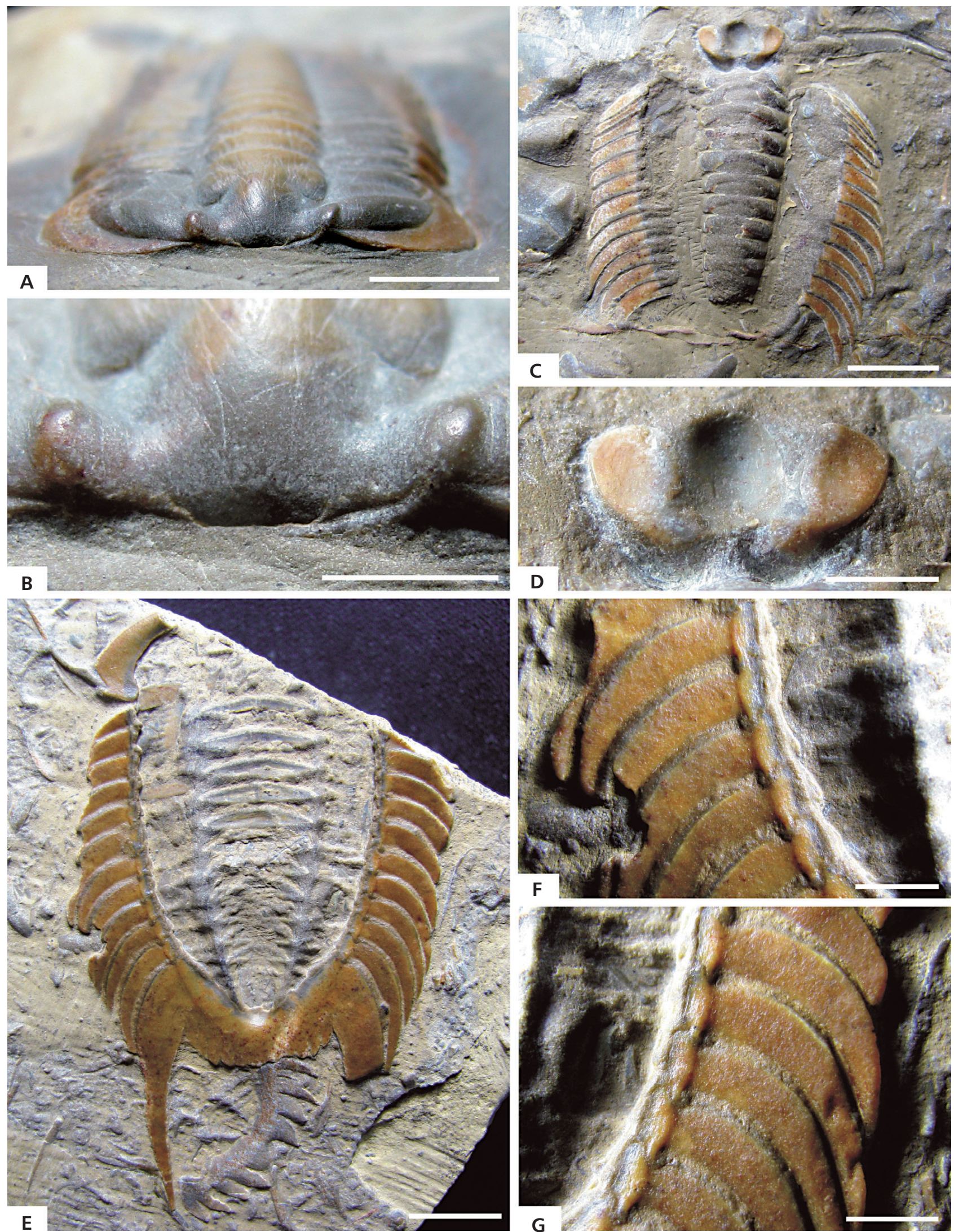

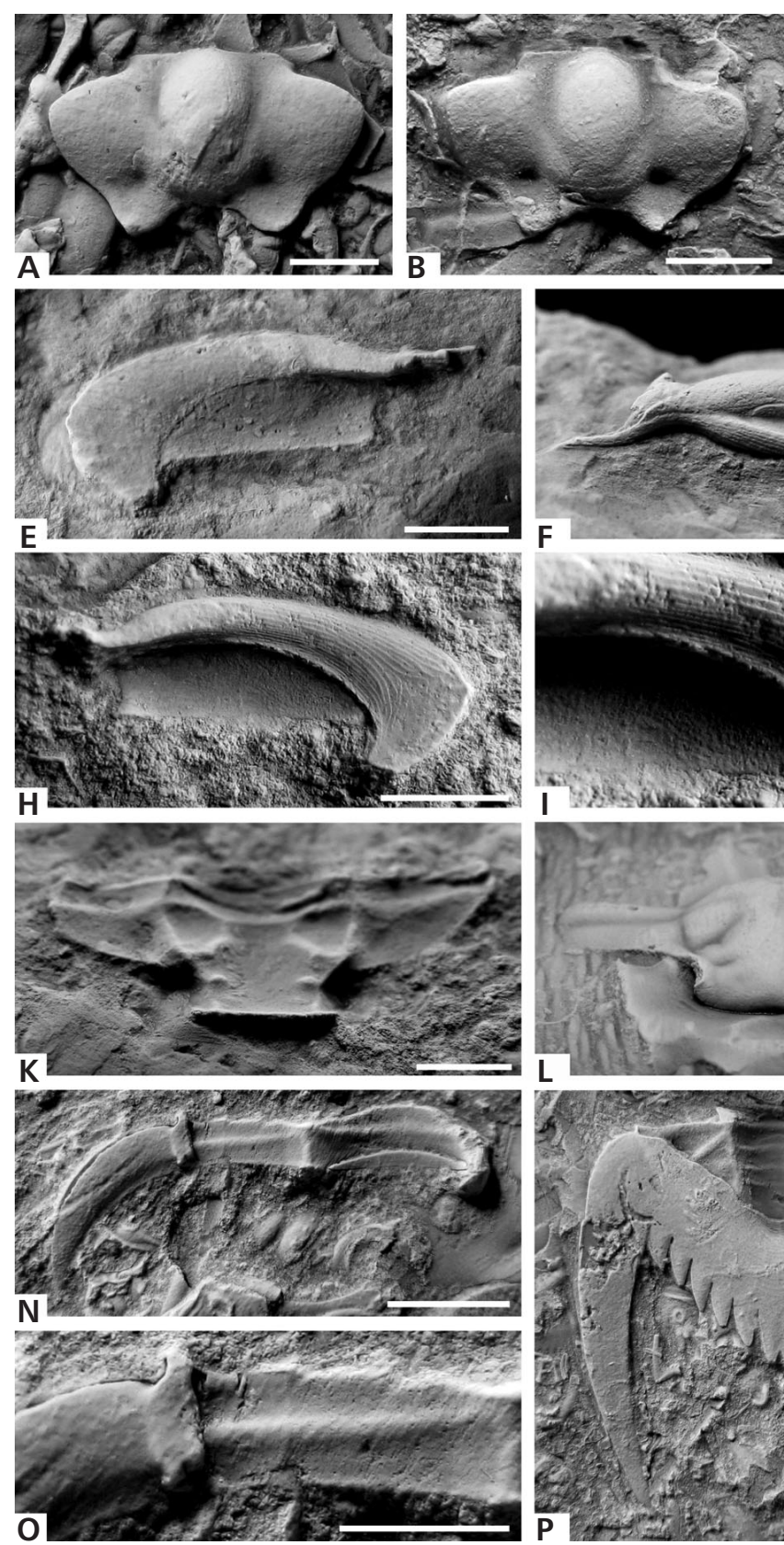
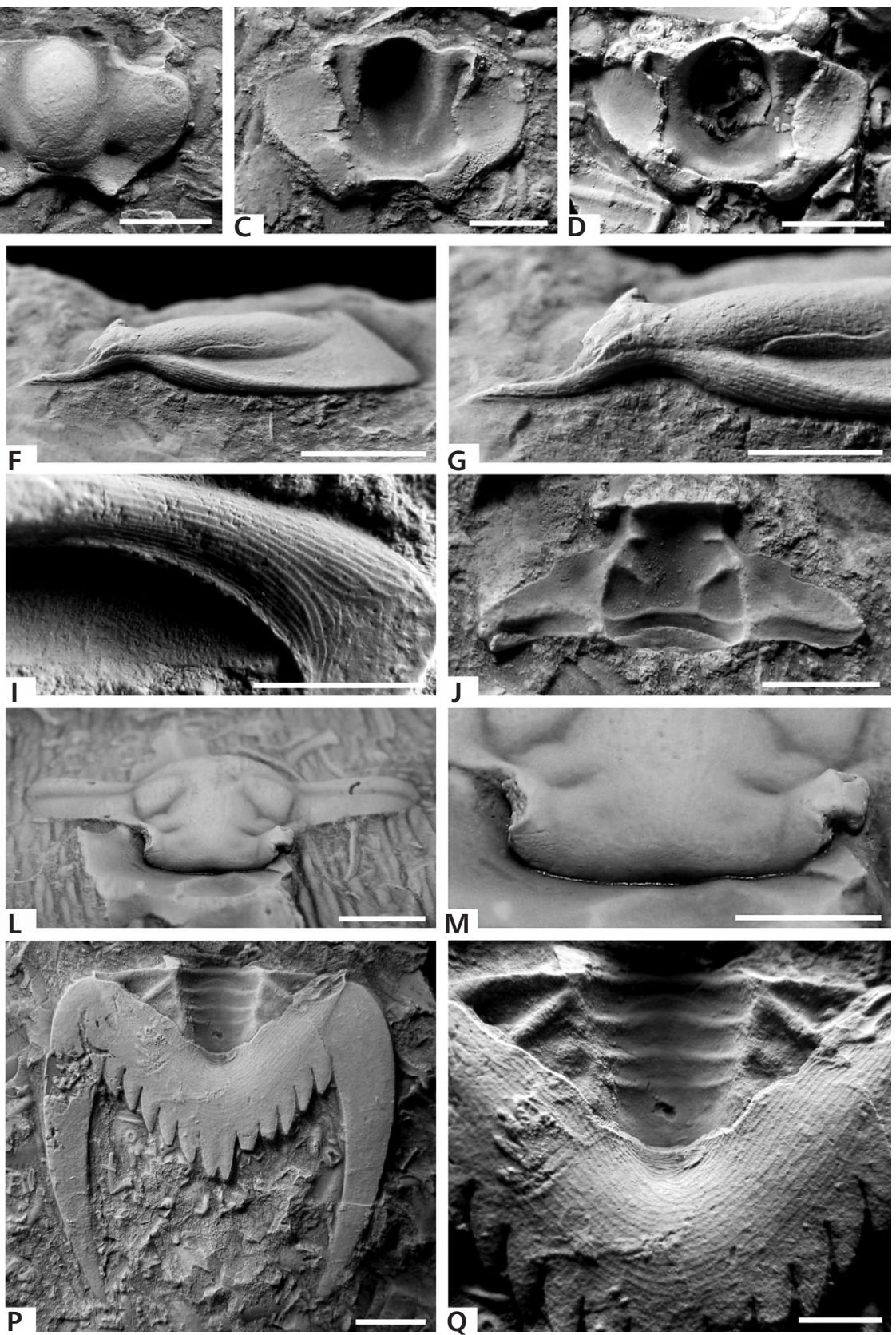

Figure 2. Neodrepanura premesnili (Bergeron, 1899), from the Kushan Formation in Laiwu, Shandong, China. • A - ELEL-LW100014, B - ELEL-LW100018, hypostome in ventral view; C - ELEL-LW100017, D - ELEL-LW100015, hypostome in dorsal view; E - ELEL-LW100023, librigena in ventral view; F, G - ELEL-LW100013, librigena in lateral view and close-up of anterior portion; H, I - ELEL-LW100024, librigena in ventral view and close-up of posterior portion of the doublure; J - ELEL-LW100016, cranidium in ventral view; K - ELEL-LW100026, cranidium in ventral and obliquely anterior view; L, M - ELEL-LW100021, cranidium in obliquely anterior view and close-up of anterior portion; N, O - ELEL-LW100019, thoracic segment in ventral view and close-up of anterior portion; P, Q-ELEL-LW100022, pygidium in ventral view and close-up of middle area. Scale bars $5 \mathrm{~mm}$ in $\mathrm{F}, \mathrm{L}, \mathrm{N}, \mathrm{P}$ and $3 \mathrm{~mm}$ in $\mathrm{A}-\mathrm{E}, \mathrm{G}-\mathrm{K}, \mathrm{M}, \mathrm{O}, \mathrm{Q}$.

belong to $N$. premesnili, our new materials demonstrate that Kobayashi's (1942) reconstruction is inaccurate, as the shoulders are reconstructed narrow (transverse) and rounded at the ends rather than sharp.

A rostral plate is lacking in some representatives of the order Asaphida, being replaced by a ventral median suture or conjoining ventrally (Fortey \& Chatterton 1988, Fortey 1990, Park \& Choi 2009). Our new materials demonstrate that the rostral plate is absent in N. premesnili; anteriorly, the doublures of the librigenae narrow and become increasingly incurved, reaching each other medially. This condition is rather unusual for a dameselloidean trilobite. 
Although no specimens with articulated hypostomes have been observed, it seems from disarticulated material that the hypostomal condition of $N$. premesnili is of the conterminent condition described by Fortey (1990). The hypostome is inferred to have attached to the anterior librigenal doublure, and aligned with the anterior edge of the glabella.

Remarkable variety of trilobite exoskeletal shapes, particularly in the cephalon, can be explained as a response to the adoption of specific feeding habits. $N$. premesnili shows exoskeletal features that Fortey \& Owens (1999) and Babcock (2003) described as consistent with a carnivorous (predator/scavenger) feeding habit. The conterminant hypostomal condition in $N$. premesnili may stabilize the hypostome against the cephalic exoskeleton, which would aid in processing prey. Lack of a rostral plate could lead to a strengthened anterior cephalic doublure. A pair of marginal spines on the hypostome of $N$. premesnili, which is similar to the fork present in some asaphids (Fortey \& Owens 1999, Babcock 2003), may have been used as an aid to process bulky food and help prevent prey escape. Furthermore, the relatively expanded glabella of $N$. premesnili may have served to accommodate more food.

Most trilobites were capable of enrollment (e.g., Moore 1959, Bergström 1973, Babcock 2003). Enrollment is complete when a posterior portion of the thorax or the pygidium was bought into contact with the ventrally or inwardly facing inner surfaces of the cephalic doublure (Clarkson \& Whittington 1997). Among dameselloidean trilobites, many enrolled specimens of Damesella have been found (e.g., Kobayashi 1942, pl. 5, figs 3-5). However, articulated sclerites of $N$. premesnili are so rare that no enrolled specimens have been discovered so far. Based on available material of $N$. premesnili, most of which is disarticulated, we infer that the fulcral structures in $N$. premesnili allowed for enrollment of the body, but the exoskeleton could not fully close laterally because the pleural spines would project around a lateral gap similar to that described in Remopleurides (Nikolaisen 1983, pl. 5; Chatterton \& Campbell 1993, fig. 4).

Hypostomal morphology is of taxonomic significance in drepanurid trilobites. The hypostome of $N$. premesnili appears similar to that of Palaeadotes hunanensis (Peng et al. 2004, pl. 39, figs 3-5; pl. 57, figs 10-13). Hypostomes of the two species differ slightly in size and in proportions of the posterior lobe of the middle body. The posterior lobe is wider than the anterior lobe in $N$. premesnili but narrower in P. hunanensis. Hypostomes of two other drepanurid species, Paradamesella typica (Peng et al. 2004, pl. 42, fig. 5; pl. 43, fig. 2) and Paradamesella peculiaris (Peng et al. 2004, pl. 44, fig. 8) exhibit many more differences from the hypostome of $N$. premesnili. They are subquadrate in outline, the shoulders are very narrow (transverse) rather than wide (transverse), and the posterior

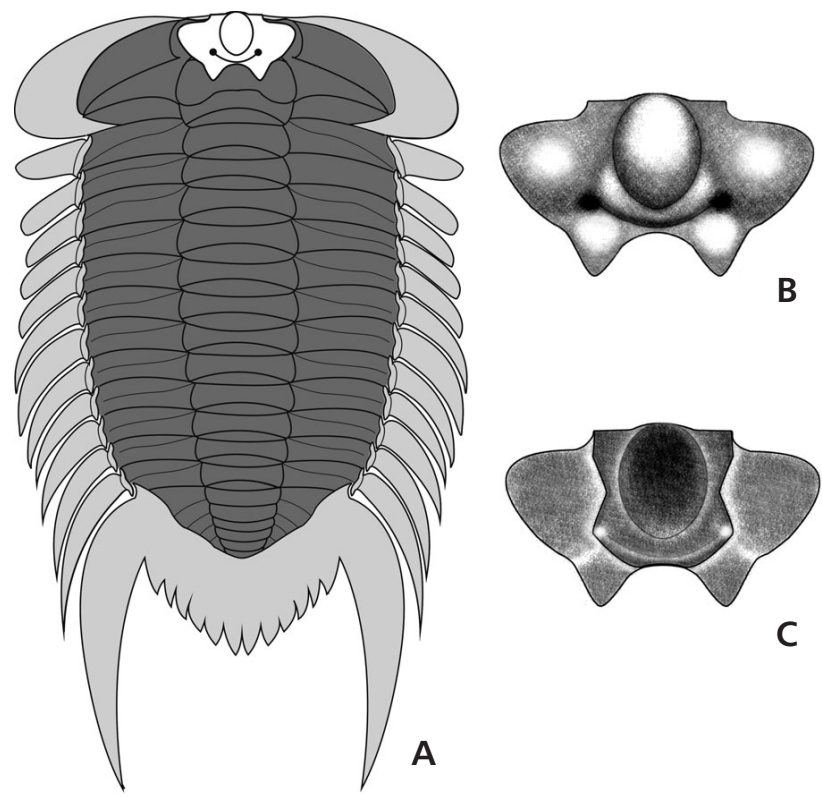

Figure 3. Reconstruction of Neodrepanura premesnili (Bergeron, 1899). $\bullet \mathrm{A}$ - complete exoskeleton in ventral view; B - hypostome in ventral view; $\mathrm{C}$ - hypostome in dorsal view.

marginal spines are short and blunt rather than sharp. These comparisons suggest Neodrepanura may be phylogenetically closer to Palaeadotes than to Paradamesella.

\section{Acknowledgments}

We particularly thank Shanchi Peng (Nanjing Institute of Geology and Palaeontology, Chinese Academy of Sciences) for his great help with this study. We are grateful to Loren E. Babcock (The Ohio State University, Ohio, USA) and Frédéric B.M. Jacques (Nanjing Institute of Geology and Palaeontology, Chinese Academy of Sciences) for providing helpful comments. We thank Haichun Zhang, Christopher Richard Hill, Jun Wang (Nanjing Institute of Geology and Palaeontology, Chinese Academy of Sciences) and Robert W. Scott (University of Tulsa, Oklahoma, USA) for all their kindly help. The comments of the reviewers Rudy Lerosey-Aubril (Senckenberg Research Institute, Frankfurt am Main) and Jih-Pai Lin (Nanjing Institute of Geology and Palaeontology, Chinese Academy of Sciences) are greatly acknowledged. Many thanks to the teachers, colleagues and friends who helped us in the writing process.

\section{References}

AIRAGHI, C. 1902. Di alcuni trilobiti della Cina. Atti della Societa Italiana di Science Naturali 41(1), 2-27.

BABCOCK, L.E. 2003. Trilobites in Paleozoic predator-prey systems, and their role in reorganization of early Paleozoic ecosystems, 55-92. In Kelley, P.A., Kowalewski, M. \& Hansen, T.A. (eds) Predator-Prey Interactions in the Fossil Record. Kluwer Academic/Plenum Publishers, New York. 
Bergeron, J.N. 1899. Étude de quelques trilobites de Chine. Bul-

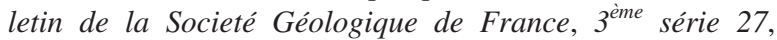
499-519.

Bergström, J. 1973. Organisation, life and systematics of trilobites. Fossils and Strata 21, 1-69.

ChANG, H.-T. 1927. Lapidarium Sinicum, a study of the rocks, fossils and metals as known in Chinese literature. Second edition, revised. Geological Survey of China Memoirs, Series B 2, 1-432. [in Chinese]

Chatterton, B.D.E \& Campbell, M. 1993. Enrolling in trilobites: a review and some new characters. Memoirs of the Association of Australasian Palaeontologists 15, 103-123.

Clarkson, E.N.K. \& Whittington, H.B. 1997. Classification, 67-74. In KAESLER, R.L. (ed.) Treatise on Invertebrate Paleontology, Part O, Arthropoda 1, Trilobita, revised. Volume 1: Introduction, Order Agnostida, Order Redlichiida. Geological Society of America \& University of Kansas Press, Boulder, Colorado \& Lawrence, Kansas.

ForTEY, R.A. 1990. Ontogeny, hypostome attachment and trilobite classification. Palaeontology 33, 529-576.

Fortey, R.A. \& Chatterton, B.D.E. 1988. Classification of the trilobite suborder Asaphina. Palaeontology 31, 165-222.

Fortey, R.A. \& Owens, R.M. 1999. Feeding habits in trilobites. Palaeontology 42(3), 429-465. DOI 10.1111/1475-4983.00080

GuO, H.-J., ZAN, S.-Q. \& LuO, K.-L. 1996. Cambrian stratigraphy and trilobites of eastern Liaoning. 142 pp. Jilin University Press, Changchun. [in Chinese with English summary]

Guo, P. 300 A.D. Êrh-ya chu shu. [A commentary on Êrh-ya.] Sung ed. Section 14, 1-28. [in Chinese]

Hupé, P. 1953. Classe des Trilobites, 44-246. In Piveteau, J. (ed.) Traité de Paléontologie 3. Masson, Paris.

Kobayashi, T. 1935. The Cambro-Ordovician formations and faunas of South Chôsen. Palaeontology, Part 3. Cambrian faunas of south Chôsen with a special study on the Cambrian trilobite genera and families. Journal of the Faculty of Science, Imperial University of Tokyo, Section 2, 4(2), 49-344.

Kobayashi, T. 1942. Studies on Cambrian trilobite genera and families 4. Japanese Journal of Geology and Geography 18(4), 197-212.

LiU, Q. \& LeI, Q. 2010. First known complete specimen of Neodrepanura (Trilobita: Damesellidae) from the Cambrian Kushan Formation, Shandong, China. Alcheringa, 1-7. DOI 10.1080/03115518.2011.519650

MonKe, H. 1903. Beiträge zur Geologie von Schantung. Part 1:
Obercambrische Trilobiten von Yen-tsy-yai. Jahrbuch Königliche Preussische Geologische Landesanstalt, Berlin 23, 103-151.

Moore, R.C. (ed.) 1959. Treatise on Invertebrate Paleontology, Part O. Arthropoda 1. i-xix +560 pp. Geological Society of America \& University of Kansas Press, Lawrence, Kansas \& Boulder, Colorado.

NeEDHAm, J. 1959. Science and civilisation in China, Volume 3, Mathematics and the sciences of the heavens and the Earth. 874 pp. Cambridge University Press, Cambridge.

Nikolaisen, F. 1983. The Middle Ordovician of Oslo Region. Part 32: Trilobites of the family Remopleurididae. Norsk Geologiske Tidsskrift 62(1982), 231-329.

ÖZDIKMEN, H. 2006. Nomenclatural changes for fourteen trilobites genera. Munis Entomology and Zoology 1, 179-189.

PARK, T.Y. \& CHOI, D.K. 2009. Post-embryonic development of the Furongian (late Cambrian) trilobite Tsinania canens: implications for life mode and phylogeny. Evolution \& Development 11, 441-455. DOI 10.1111/j.1525-142X.2009.00350.x

PENG, S.-C. 2007. Historical review of trilobite research in China, 171-191. In Mikulic, D.G., Landing, E. \& Kluessendorf, J. (eds) Fabulous Fossils, 300 Years of Worldwide Research on Trilobites. New York State Museum Bulletin 507.

Peng, S.-C., BABCock, L.E. \& Lin, H.-L. 2004. Polymerid trilobites from the Cambrian of Northwestern Hunan, China, Volume 1. 303 pp. Science Press, Beijing.

Schoетt, H. 1891. Beiträge zur Kenntnis kalifornischer Collembola. Bihang Till Kungliga Svenska Vetenskapsakademiens Handlingar, Band 17, 5(8), 1-25.

ST. John, J. 2007. The earliest trilobite research (antiquity to the 1820S), 201-211. In Mikulic, D.G., LANDing, E. \& KLUESSENDORF, J. (eds) Fabulous Fossils, 300 Years of Worldwide Research on Trilobites. New York State Museum Bulletin 507.

WalcotT, C.D. 1913. The Cambrian faunas of China, 3-276. In Research in China, vol. 3, Carnegie Institution of Washington, Publication 54.

Zhang, W.-T. 2003. Cambrian biostratigraphy of China, 55-119. In Zhang, W.-T., Chen, P.-J. \& Palmer, A.R. (eds) Biostratigraphy of China. Science Press, Beijing.

Zhang, W.-T. \& Jell, P.A. 1987. Cambrian Trilobites of North China. 459 pp. Science Press, Beijing.

Zhu, N.-W. 1992. Class Trilobita, 334-369. In Jilin Bureau OF Geology Science and Mineral Resoures (ed.) Palaeontological Atlas of Jilin, China. Jilin Science and Technology Publishing House, Changchun. [in Chinese] 